\title{
Vývoj hráčské struktury a podíl cizinců na herním výkonu družstev extraligy mužů v basketbalu v České republice
}

\section{The development of team's structure of the Czech national basketball league and share of foreigners in gaming performance}

\author{
Emil Řepka, Jiří Bubák
}

\author{
Pedagogická fakulta Jihočeské univerzity v Českých Budějovicích
}

\begin{abstract}
Abstrakt
Studie se zaměruje na problematiku složení družstev v české nejvyšši basketbalové soutěži - extralize mužů, od sezóny 1998/99 do ročníku 2008/ 09. Sledovaný soubor hráču je rozdělen do tři skupin: Češi do 20 let, Češi nad 20 let včetnè, a cizinci. Základní metodou šetření byla obsahová analýza herních statistik utkání - počet hráčů, počet odehraných minut, počet vstřelených bodů, koeficient užitečnosti a údaje o složení družstev. Výsledky potvrdily předpokládaný nárůst počtu cizinců v jednotlivých družstvech a jejich stále se zvyšující vliv - $v$ naší studii prezentovaný koeficientem užitečnosti hráču - na probíhající zápasy extraligy. Trend začlenění a prínosu českých hráču se ukázal být naopak klesající. Naše předpoklady tak byly potvrzeny. Práce poukazuje svými výsledky na změny ve složení jednotlivých hráčských družstev.
\end{abstract}

\begin{abstract}
This article looks at the evolution of structure teams in the highest Czech basketball league. The tracking period is since seasons 1998/99 to 2008/09. This research is based on content analysis of game statistics from particular games. The sample of players is classified into three groups (Czech players younger than twenty years, Czech players twenty years old and older, foreign players) and evaluates statistical characteristics by the comparative method. These include the number of players, minutes played, points scored and coefficient of usefulness. The results confirm the expected increase of the number of foreign players as well as continuously growing impact on the game. The impact is expressed as a coefficient of player's utility. In contrast to this, the trend of participation and usefulness of Czech players younger than twenty years is shown to be diminishing. The hypotheses of our studies are therefore proven valid. The article refers to the change of the team constitution.
\end{abstract}

Kličová slova: $\quad$ basketbal; extraliga NBL; herní statistika; národnostní struktura; složení družstva Keywords: $\quad$ basketball; extra league NBL; game statistics; national structure; team constitution

\section{ÚVOD}

Basketbal se nikdy nezastavil na nějakém pomyslně konstantním místě a už od svého vzniku v roce 1891 se v různé podobě ubírá neustále vpřed. Postupem času se stal jedním z nejrozšířenějších, nejoblíbenějších a nejsledovanějších sportů na naší planetě. Jeho význam překračuje hranice sportovního prostředí a stává se společenským jevem s globálním, sociálním dopadem (e.g. Galily \& Sheard, 2002; Cingiene \& Laskiene, 2004)).

Vlajkovou lodí každé země je nejvyšší mužská soutěž. Ta by měla být určujícím elementem pro popularitu košíkové a hlavním motivačním faktorem pro začínající sportovní mládež. Česká extraliga mužů se v posledních dvaceti letech proměnila k nepoznání. Ze soutěže plné českých hráčůu, talentovaných mladíků a v neposlední řadě i českých trenérů, se stává mezinárodní kolbiště, ve kterém se čím dál víc začíná projevovat nedostatek konkurence schopných hráčů z České republiky. Basketbalisté, fanoušci, ale i nezaujatí televizní diváci dnes mohou několikrát do týdne shlédnout unikum, jež nemá v našich kolektivních sportech obdobu. Vidí ligu plnou cizinců, zahraničních trenérů. Ligu, v níž se žádný z profesio- 
nálů neobejde bez znalosti anglického jazyka, protože i čeští trenéři většinou hovoří ke všem svým svěřencům v angličtině.

Celosvětová společnost se díky rozvoji nových informačních technologií neustále přibližuje. Za basketbalový vzor se obecně považuje americká NBA a v poslední době i evropská Euroliga. V tradičních basketbalových baštách je nepřeberné množství profesionálů dychtících po slávě, úspěchu nebo jen smlouvě, zaručující adekvátní př́ijem. Pro ambiciózní a finančně zajištěné kluby proto není žádný problém vábit zahraniční hráče do svých týmů. Jejich majitelé toho plně využívají, protože vedení, sponzoři a fanoušci mají jen ty nejvyšší cíle. Je zde však několik aspektů, nad kterými je potřeba se zamyslet. Nastává totiž doba, kdy hráčská zahraniční konkurence se stále více prosazuje v basketbalových extraligových družstvech. Tento trend není jen záležitostí naší země. V širším kontextu je registrován např. v Izraeli (cf. Shor \& Yonay, 2010). Podstatou naší práce je zmapovat vývoj struktury družstev v extralize mužů od sezony 1998/1999 do 2008/09. Zvláštní pozornost věnujeme národnostnímu hráčskému složení jednotlivých družstev.

\section{PROBLÉM}

Současný basketbal se v posledním období zrychlil, a to jak pohybem hráčů, tak řešením herních situací. Začíná se o něm hovořit jako o „non-stop game“, tedy jako o sportovní hře, v níž téměř nenalézáme hluchá místa a zpomalovací fáze. Takové pojetí, klade značné nároky na kolektivní výkon družstva a hráče jako jednotlivce (Smith, 1998; Karger \& Velenský, 1999; Velenský, 1999; Ostojic, Mazic, \& Dikic, 2006, Sampaio, Janiera, Ibanez, \& Lorenzo, 2006). V obecnější rovině lze tvrdit, že se na košíkové v posledních letech podílela a dosud podílí celá řada událostí a převratných změn celosvětového významu.

Změny lze vymezit do dvou vzájemně determinujících subsystémů. První, společenské a ekonomické aspekty, mají obecnější dopad a svým způsobem limitují sportovní hru. Druhou - změny v pojetí sportovní hry, které jsou konkrétnější a ukazují svými teoretickými a praktickými závěry na změny v pojetí herního výkonu (Nykodým et al., 2006 s. 33).

Vývoj basketbalu se zhruba od konce osmdesátých let minulého století značně urychlil. Přisuzujeme to především:

1. Komercionalizaci sportu, s níž jde ruku v ruce medializace.

2. Geopolitickým změnám, které způsobily rozpad socialistických států a rozšiřrení Evropské unie.

3. Naprosto bezbariérovým možnostem přenosu informací.

4. Vstupu hráčů a družstev NBA do soutěží FIBA.

Upřesněním těchto okolností zjištujeme:

1. Rozdělení basketbalu na amatérský a profesionální. Za vyspělost v obou částech mohou ekonomické možnosti jednotlivých států, klubů a škol.

2. Sporty na profesionální úrovni, basketbal nevyjímaje, se hrají pro pobavení diváků. Atraktivita herního výkonu se stala nezbytnou podmínkou jeho existence.

3. Volný pohyb hráčů a jejich přesun po celém světě. Basketbalový trh se začal řídit zásadami nabídky a poptávky. Tím roste hráčská konkurence, vytvářející zvyšující požadavky na kvalitu individuálních herních výkonů.

4. Vznikem nových států (213 členských zemí FIBA) došlo ke zvýšení konkurence na mezinárodních kolbištích, na klubové i reprezentační úrovni.

5. Neustálou konfrontaci různých pojetí basketbalu.

O současném basketbalu lze s mírnou dávkou nadsázky tvrdit, že to, co se zdá být progresivní, rychle zastarává nebo podléhá změnám. „Herní krásu“ nahrazuje účelnost. Účelnost směřuje k dokonalosti (jakkoli k současné basketbalové dokonalosti lze zaujímat různá stanoviska). Dokonalost je podmíněna zvládnutím základů sportovní hry (dům nelze stavět od střechy). Sponzory zajímá nikoli výkon, ale výsledek. Výsledky podléhají odhadům a kalkulacím. Tyto odhady a kalkulace jsou poměrně přesné, nebot si všímají výkonového potenciálu jednotlivých hráčů. Zdůrazňuje se efektivita výkonu (Velenský, 1999, s. 12). 
Sportovní výkon je jednou z hlavních kategorií sportu a sportovního tréninku. Podle Dovalila (2009) umožňuje interpretovat systémový př́istup, jako vymezený systém prvků, který má určitou strukturu, tj. zákonité uspořádání a propojení sítí vzájemných vztahů. Ovlivňují ho faktory, které chápeme jako relativně samostatné součásti sportovních výkonů, vycházející ze somatických, kondičních, technických, taktických a psychických základů výkonu. Dají se natrénovat a bere se na ně ohled při výběru talentovaných jedinců. V košíkové chápeme výkon jako individuální a skupinové jednání hráčů v jednotlivých fázích utkání. Projevuje se mírou splnění herních činností. V porovnání s individuálními sporty má tento výkon své odlišnosti. Ty jsou hlavně dány nestálostí jeho podmínek, tj. značnou proměnlivostí nastalých situací a nutností zdolat stálý odpor protivníka. Důraz je kladen na rychlost reakce a volbu optimálního, co nejjednoduššího řešení situace. V basketbalu rozlišujeme dva druhy herního výkonu. Individuální (výkon hráče) a týmový (výkon družstva). Charakterizovat můžeme tyto činnosti mírou splnění herních úkolů, jejichž důsledkem je výsledek zápasu. (Rose, 2004; Nykodým et al., 2006). „Sportovní výkon basketbalového družstva je výkon sociální skupiny zvláštního druhu, založený na individuálních výkonech hráčů, podléhajících vzájemnému regulačnímu působení, jež se projevuje tím, že hráči ovlivňují své jednání i chování skupiny jako celku. Jediným vyjádřením výkonu družstva je výsledek dosažený v utkání proti konkrétnímu soupeři“ (Dobrý, Velenský, 1987, s. 15). Výkon týmu ovlivňuje jeho vnitřní uspořádání, tj. systém postavení a rolí členů v mužstvu. Zásadní vliv, určující úspěšnost kolektivu, mají: koheze (soudržnost), participace (účast), autorita, motivace a komunikace. Výkon družstva lze analyzovat na základě pozorování a posuzování nebo dat získaných z průběhu utkání a popsat je číselnými charakteristikami. K těmto charakteristikám např̀ patří počet pokusů o střelbu a jejich úspěšnost, počet doskočených míčů, počet získaných a ztracených míčủ, asistence při střelbě na koš, získané a spáchané fauly a další. „Týmový herní výkon je založen na individuálních herních výkonech, které podléhají vzájemnému regulačnímu působení "(Dobrý, Semiginovský, 1988, s. 47). Výkon hráče v utkání lze zaznamenávat a hodnotit podle určitých ukazatelů. Ty zachycují pomocí číselných charakteristik kritická místa jednání hráče, tj. taková, která se podstatnou měrou podílejí na výkonu celého družstva. Jsou to: docílené body, poměr úspěšné a neúspěšné stř̌elby trestných hodů i z pole (i podle vzdálenosti od koše, postavení na hřišti, způsobu střelby a způsobu obrany proti ní) doskočené míče v obraně i útoku, zisky a ztráty míče, osobní chyby získané a spáchané, asistence - přihrávky lépe postaveným spoluhráčům, kteří díky nim vstřelí koš, účast na kombinacích, způsob a úspěšnost individuálního krytí atd. Většina $\mathrm{z}$ těchto ukazatelů je povinně zaznamenávána $\mathrm{v}$ tzv. herních statistikách (technických zápisech) z utkání extraligy žen a mužů, a také na mezinárodním poli.

\section{METODIKA}

Cílem naší práce je zmapování dynamiky hráčské struktury basketbalových družstev extraligy mužů. Dílčí úkoly jsou: zjištění podílu českých hráčů, cizinců a českých hráčů do 20 let v týmech basketbalové extraligy mužů (Mattoni NBL), jejich začlenění a přínos pro tým podle podrobné herní statistiky utkání v sezonách 1998/1999 - 2008/2009. Předpokládáme nárůst všech sledovaných statistických údajů u cizinců v rozmezí sezon a s ním spojený pokles využitelnosti českých basketbalistů. Dalším naším pracovním předpokladem je mírný pokles všech sledovaných statistických údajů u českých hráčủ do 20 let v rozmezí sezon 1998/1999 - 2008/2009. Zkoumaný soubor tvoří hráči nejvyšší basketbalové soutěže mužů extraligy NBL v sezónách počínaje 1998/99 a konče sezónou 2008/09. Hlavní metodou zpracování je obsahová analýza. Zaměřujeme se na okruhy: zdroje herních statistik ze zápasů NBL od sezóny 1998/99, zdroje vývoje omezení počtu cizinců v NBL od sezóny 1998/99. V současnosti se v našich soutěžích řízených Českou basketbalovou federací (dále jen ČBF) dělají herní statistiky pouze z utkání extraligy mužů (dále jen NBL) a extraligy žen (ŽBL). V této práci využíváme hodnocení výkonu hráče podle herních statistik z oficiálního webu ČBF (www.cbf.cz), které jsou v plném rozsahu pro NBL dostupné od sezony 1998/1999. V současnosti se herní statistika zapisuje prŕmo během utkání do počítačového programu, který zpracovává a okamžitě předává výsledky již během utkání na internet. ČBF k tomu využívá software pro zpracování herních statistik, program TZW. Údaje z utkání zpracovává pouze oprávněná osoba s licencí zpracovatele herních statistik, čímž ČBF předchází nejednotnosti dat. 


\section{Ukazatele herní statistiky ČBF:}

- Minuty: přesný čas, který jednotlivý hráč stráví na palubovce v utkání

- Střelba:

- $\quad z$ pod koše - počet proměněných střel z celkového počtu pokusů ze vzdálenosti do 2 metrů od koše

- za 1 bod - počet proměněných střel z celkového počtu pokusů ze vzdálenosti čáry trestného hodu

- $\quad$ za 2 body - počet proměněných střel $\mathrm{z}$ celkového počtu pokusů ze vzdálenosti mezi vymezeným územím a čárou tř́ibodového území

- $\quad$ za 3 body - počet proměněných střel $\mathrm{z}$ celkového počtu pokusů ze vzdálenosti více jak $6,25 \mathrm{~m}$ od koše

- Doskok:

- útočný - zisk míče po neúspěšné střelbě své či spoluhráče

- obranný - zisk míče po neúspěšné střelbě soupeře

- Blok - zásah míče vystřeleného soupeřem předtím než dosáhne kulminačního bodu a tím zabránění obdržení koše

- Asistence - přihrávka spoluhráči do takové pozice, která vede $\mathrm{k}$ úspěšnému zakončení bez driblinku

- Zisk míče - obránce získá kontrolu nad míčem, který měl před tímto momentem pod kontrolou soupeř

- Ztráta míče - ztráta kontroly míče, kontrolu nad míčem přebírá soupeř

- Osobní chyba:

- $\quad$ spáchaná - porušení pravidel a obdržení osobní, technické, nesportovní, poprípadě diskvalifikační chyby

- $\quad$ získaná - aktivitou donutit soupeře k porušení pravidel tak, že obdrží osobní, technickou, nesportovní nebo diskvalifikační chybu

- Koeficient užitečnosti: rating hráče ze zápisu herních statistik o utkání

- Body: Součet proměněných střeleckých pokusů vynásobených odpovídající hodnotou dosaženého koše (za 1 bod, za 2 body či za 3 body)

\section{Koeficient užitečnosti}

Z údajů ČBF (http://www.cbf.cz/souteze/vysvetlivky.html) se výpočet koeficientu užitečnosti (ratingu) hráče v utkání počítá podle vzorce:

Koeficient užitečnosti $=(\mathrm{b})+(\mathrm{DC})+(\mathrm{Bl})+(\mathrm{As})+(\mathrm{M}+)+(\mathrm{F}+)-(\mathrm{S}-)-(\mathrm{M}-)-(\mathrm{F}-)$

Vysvětlivky:

(b) - počet vstřelených bodů

(DC) - doskoky celkem (součet útočných a obranných doskoků)

(Bl) - bloky

(As) - asistence

$(\mathrm{M}+)$ - získané míče

$(\mathrm{F}+)$ - získané fauly

(S-) - počet neúspěšných střeleckých pokusů (dvoubodových, tř́bodových i trestných hodů)

(M-) - ztracené míče

(F-) - spáchané fauly

\section{Jména klubů NBL použitá v naší práci a jejich oficiální názvy v průběhu let 1998-2009:}

- BBK Brno - BBK Orgapol Brno, BBK Houseři Brno, Triga Eprin Brno, Triga Brno, Houseři Brno, Handicap Brno, BBK IVes Brno

- $\quad$ BC Brno - BVV Draci Brno, BVV Brno, BC BVV ŽS Brno BC, A PLUS ŽS Brno BC, A PLUS OHL ŽS Brno BC

- Děčín - BK SČE Děčín, BK Děčín

- Chomutov - BK ASK Chomutov, BK Chomutov

- Kroměříž - BK Slavia Kroměříž, BC Slavia Kroměříž 
- Kolín - BC Kolín

- $\quad$ Liberec - BK Kondoři Liberec

- Nový Jičín - Mlékárna Kunín, Geofin Nový Jičín

- $\quad$ Nymburk - BK GA Nymburk, BK ECM Nymburk, ČEZ Basketball Nymburk

- Opava - BK Slovnaft Opava, BK Opava, BK Breda \& Weinstein Opava

- Ostrava - BK NH Ostrava, NH Ostrava

- Pardubice - Ostacolor Pardubice, Ostacolor BK Pardubice, BK Synthesia Pardubice

- Poděbrady - BK Sadská, Karma Basket Poděbrady

- Prostějov - BK Prostějov USK Praha - USK Erpet Praha

- Sparta Praha

- Ústí n. Labem - BK Spolchemie Ústí nad Labem, BK SČP Ústí nad Labem, BK Ústí nad Labem

- Vyšehrad - Sokol Vyšehrad, Sokol CIPA Vyšehrad

Výzkumný soubor byl rozdělen do tř́ skupin- Češi nad 20 let, cizinci a Češi do 20 let. Kategorie Čech do 20 let je definována jako věk hráče, kterému před započetím nadcházející sezóny není 20 a více let. Poslední zápasy finále play off se odehrávají v průběhu května, proto jsme za určující termín stanovili 1. červen. Např́́klad v sezóně 1998/99 toto kritérium splňuje každý hráč narozený po1.6.1979. Kategorie cizinec je hráč, který nemá státní občanství ČR. Splnění kritéria minimální hrací doby je dáno 5\% maximální možné hrací doby jednoho hráče v sezóně. Ze zápisů herních statistik jsme za základní ukazatele spadající do sledovaných skupin stanovili: počet hráčů, počet odehraných minut, počet vstřelených bodů, koeficient užitečnosti.

\section{VÝSLEDKY A DISKUSE}

Vzhledem k omezeným prostorovým možnostem uvádíme $\mathrm{v}$ našem příspěvku přehled dat formou tabulek z počátečního a konečného roku sledování. Viz tabulky 1 a 2 . Ve vybraných ukazatelích je kontinuita uvedena v grafické formě. Blíže obrázek 1, 2, 3, a 4.

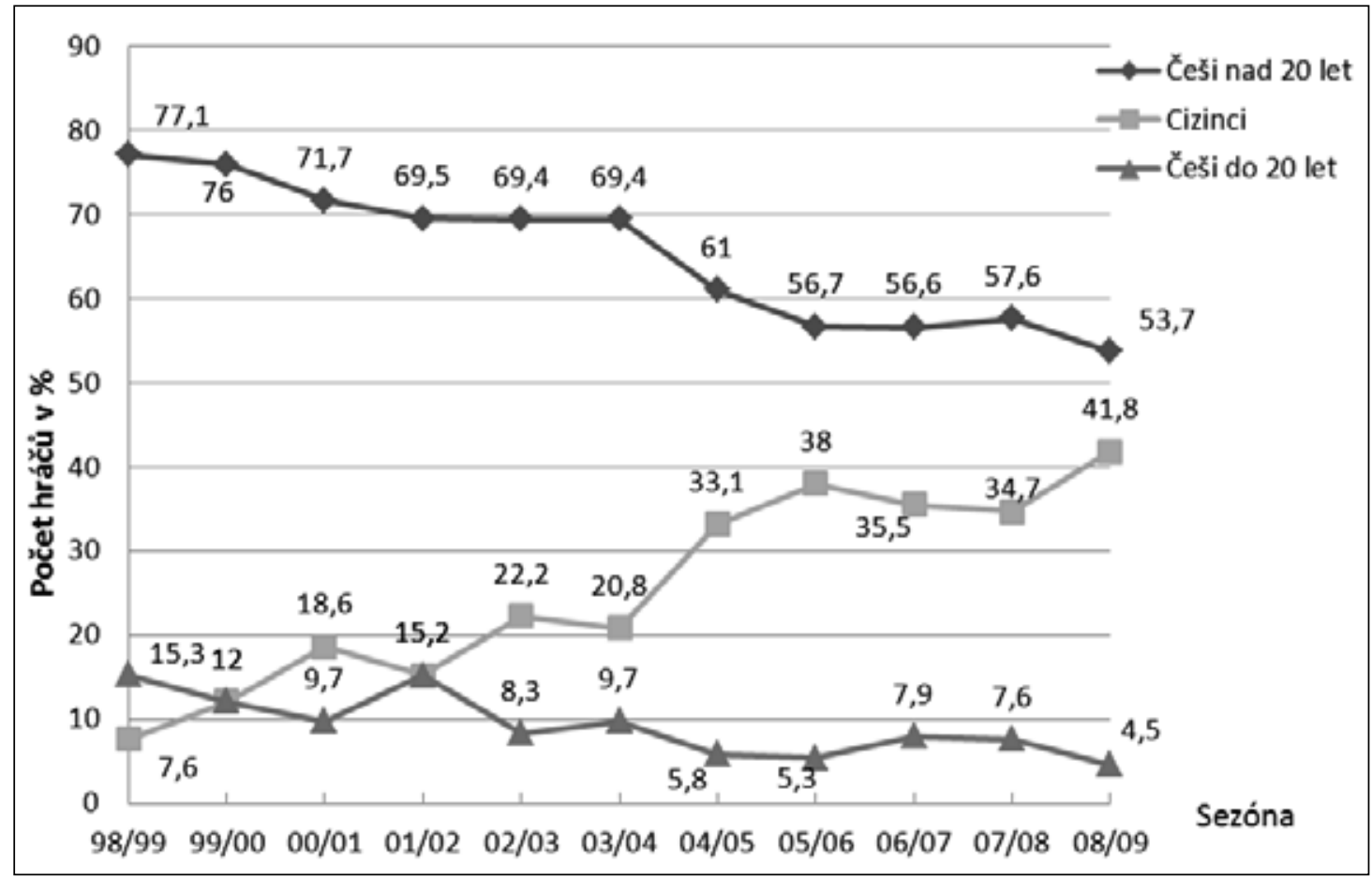

Obrázek 1. Procentuální zastoupení kategorií hráčů v extralize mužů. 
Tabulka 1. Statistika sezóny 1998/99

\begin{tabular}{|c|c|c|c|c|c|c|c|c|c|c|c|c|c|c|}
\hline & & & & & & & & EZÓNA & 998 / 99 & & & & & \\
\hline Umis & těni týmu & 1. & 2. & 3. & 4. & 5. & 6. & 7. & 8. & 9. & 10. & 11. & 12. & \\
\hline & Tým & $\begin{array}{l}\text { Nový } \\
\text { Jičín }\end{array}$ & $\begin{array}{c}\text { USK } \\
\text { Praha }\end{array}$ & Opava & Ostrava & $\begin{array}{c}\text { BC } \\
\text { Brno }\end{array}$ & Děčín & $\begin{array}{l}\text { Sparta } \\
\text { Praha }\end{array}$ & Chomutov & $\begin{array}{l}\text { BBK } \\
\text { Brno }\end{array}$ & $\begin{array}{l}\text { Ústín. } \\
\text { Labem }\end{array}$ & Pardubice & $\begin{array}{c}\text { Vyšehrad } \\
\text { Praha } \\
\end{array}$ & \\
\hline & čet zápasủ & 42 & 43 & 43 & 44 & 37 & 35 & 35 & 35 & 38 & 38 & 38 & 38 & \\
\hline $5 \% \mathrm{mi}$ & inut na hráče & 105 & 107,5 & 107,5 & 110 & 92,5 & 87,5 & 87,5 & 87,5 & 95 & 95 & 95 & 95 & Celkem \\
\hline & Celkem & 11 & 11 & 13 & 13 & 12 & 12 & 11 & 11 & 12 & 12 & 13 & 13 & 144 \\
\hline 兽 & Češi>20let & 7 & 9 & 12 & 9 & 10 & 11 & 6 & 8 & 11 & 8 & 11 & 9 & $111(77,1 \%)$ \\
\hline 芯 & Cizinci & 4 & 2 & 1 & 2 & 0 & 0 & 0 & 0 & 1 & 1 & 0 & 0 & $11(7,6 \%)$ \\
\hline & Češi<20let & 0 & 0 & 0 & 2 & 2 & 1 & 5 & 3 & 0 & 3 & 2 & 4 & $22(15,3 \%)$ \\
\hline & Celkem & 8349 & 8567 & 8644 & 8751 & 7405 & 7025 & 6781 & 6872 & 7526 & 7595 & 7432 & 7435 & 92382 \\
\hline 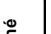 & Češi>20let & 5219 & 5850 & 8023 & 7513 & 6418 & 6716 & 4276 & 5306 & 7015 & 5508 & 6854 & 5601 & $74299(80,4 \%)$ \\
\hline 䨔 突 & Cizinci & 3130 & 2717 & 621 & 668 & 0 & 0 & 0 & 0 & 511 & 442 & 0 & 0 & $8089(8,8 \%)$ \\
\hline$\overline{\mathrm{z}}$ & Češi<20let & 0 & 0 & 0 & 570 & 987 & 309 & 2505 & 1566 & 0 & 1645 & 578 & 1834 & $9994(10,8 \%)$ \\
\hline 증 & Celkem & 3435 & 3410 & 3442 & 3446 & 2891 & 2634 & 2558 & 2810 & 2734 & 2818 & 2776 & 2540 & 35384 \\
\hline$\stackrel{8}{8}$ & Češi>20let & 2223 & 2055 & 3076 & 2911 & 2555 & 2543 & 1473 & 2198 & 2671 & 2106 & 2674 & 2015 & $28446(80,4 \%)$ \\
\hline$\frac{\bar{\omega}}{\omega}$ & Cizinci & 1202 & 1355 & 366 & 301 & 0 & 0 & 0 & 0 & 117 & 187 & 0 & 0 & $3528(10,0 \%)$ \\
\hline $\bar{n}^{n}$ & Češi<20let & 0 & 0 & 0 & 134 & 336 & 91 & 1085 & 612 & 0 & 525 & 102 & 525 & $3410(9,6 \%)$ \\
\hline & Celkem & 3093 & 3427 & 3736 & 3242 & 2798 & 2529 & 2711 & 2774 & 2579 & 2628 & 2345 & 2281 & 34953 \\
\hline$\pm \overline{0}$ & Češi>20let & 2209 & 1868 & 3362 & 2922 & 2462 & 2455 & 1692 & 2137 & 2487 & 2063 & 2318 & 1672 & $27647(79,1 \%)$ \\
\hline 总, 㫐 & Cizinci & 1692 & 1559 & 374 & 231 & 0 & 0 & 0 & 0 & 92 & 158 & 0 & 0 & $4108(11,8 \%)$ \\
\hline$\underline{x}$ & Češi<20let & 0 & 0 & 0 & 89 & 336 & 74 & 1019 & 637 & 0 & 407 & 27 & 609 & $3198(9,1 \%)$ \\
\hline
\end{tabular}

Vysvětlivky: Češi mladší než 20 let - hráči narození po 1. 6. 1979

Tabulka 2. Statistika sezóny 2008/09

\begin{tabular}{|c|c|c|c|c|c|c|c|c|c|c|c|c|c|}
\hline \multicolumn{2}{|c|}{ Umístění týmu } & 1. & 2. & 3. & 4. & 5. & 6. & 7. & 8. & 9. & 10. & 11. & \\
\hline \multicolumn{2}{|r|}{ Tým } & Nymburk & $\begin{array}{l}\text { Nový } \\
\text { Jičín }\end{array}$ & Děčín & Prostějov & Liberec & Ostrava & Opava & $\begin{array}{c}\text { USK } \\
\text { Praha } \\
\end{array}$ & Pardubice & Kolín & Poděbrady & \\
\hline \multicolumn{2}{|c|}{ Počet zápasů } & 50 & 50 & 47 & 48 & 45 & 44 & 43 & 43 & 40 & 40 & 40 & \\
\hline \multicolumn{2}{|c|}{$5 \%$ minut na hráče } & 125 & 125 & 117,5 & 120 & 112,5 & 110 & 107.5 & 107,5 & 100 & 100 & 100 & Celkem \\
\hline \multirow{4}{*}{ 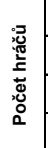 } & Celkem & 12 & 12 & 12 & 13 & 11 & 14 & 11 & 12 & 12 & 14 & 11 & 134 \\
\hline & Češi>20let & 6 & 5 & 8 & 5 & 8 & 6 & 9 & 5 & 5 & 8 & 7 & $72(53,7 \%)$ \\
\hline & Cizinci & 6 & 7 & 4 & 8 & 2 & 6 & 2 & 4 & 7 & 6 & 4 & $56(41,8 \%)$ \\
\hline & Češi<20let & 0 & 0 & 0 & 0 & 1 & 2 & 0 & 3 & 0 & 0 & 0 & $6(4,5 \%)$ \\
\hline \multirow{4}{*}{ 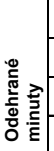 } & Celkem & 10021 & 9946 & 9395 & 9077 & 8864 & 8736 & 8453 & 8632 & 7706 & 7878 & 8110 & 96826 \\
\hline & Češi>20let & 4931 & 3405 & 5541 & 3058 & 6608 & 4016 & 6446 & 3164 & 2885 & 3328 & 5363 & $48745(50,3 \%)$ \\
\hline & Cizinci & 5090 & 6541 & 3854 & 6019 & 2096 & 4425 & 2007 & 3833 & 4821 & 4550 & 2755 & $45991(47,5 \%)$ \\
\hline & Češi<20let & 0 & 0 & 0 & 0 & 160 & 295 & 0 & 1635 & 0 & 0 & 0 & $2090(2,2 \%)$ \\
\hline \multirow{4}{*}{ 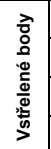 } & Celkem & 4609 & 4136 & 3856 & 3753 & 3667 & 3439 & 3298 & 3204 & 3020 & 3074 & 3405 & 39461 \\
\hline & Češi>20let & 1942 & 1181 & 2168 & 953 & 2399 & 1383 & 2363 & 1086 & 1074 & 1128 & 2140 & $17817(45,2 \%)$ \\
\hline & Cizinci & 2667 & 2955 & 1688 & 2800 & 1207 & 1974 & 935 & 1524 & 1946 & 1946 & 1265 & $20907(53,0 \%)$ \\
\hline & Češi<20let & 0 & 0 & 0 & 0 & 61 & 82 & 0 & 594 & 0 & 0 & 0 & $737(1,9 \%)$ \\
\hline \multirow{4}{*}{ 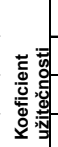 } & Celkem & 5507 & 5037 & 4129 & 3952 & 3902 & 3320 & 3201 & 3257 & 3139 & 3142 & 3387 & 41973 \\
\hline & Češi>20let & 2523 & 1375 & 2254 & 931 & 2641 & 1236 & 2464 & 1025 & 1070 & 1064 & 1989 & $18572(44,2 \%)$ \\
\hline & Cizinci & 2984 & 3662 & 1875 & 3021 & 1226 & 2035 & 737 & 1664 & 2069 & 2078 & 1398 & $22749(54,2 \%)$ \\
\hline & Češi<20let & 0 & 0 & 0 & 0 & 35 & 749 & 0 & 568 & 0 & 0 & 0 & $652(1,6 \%)$ \\
\hline
\end{tabular}

Vysvětlivky: Češi mladší než 20 let - hráči narození po 1. 6. 1989 
Vývoj národnostního složení hráčů extraligy zachycuje obrázek 1. V sezóně 1998/99 jich fakticky bylo jen 11. V roce 2008/09 56. Původně postupný plynulý nárůst $v$ tomto ukazateli změnil ročník 2004/05. V tomto roce přibylo v lize $12,3 \%$ cizinců. Počet nejmladších hráčů je závislý na síle jednotlivých mládežnických ročníků. S nárůstem migrace velmi dobrých zahraničních hráčů do České republiky, kteří dřive směřovali do vyspělých evropských „basketbalových“ států má české basketbalové mládí v nejvyšší mužské soutěži stále menší zastoupení. Z mladých Čechů splnilo určená kritéria pro participaci v extraligových mužstvech pouze 6 osob.

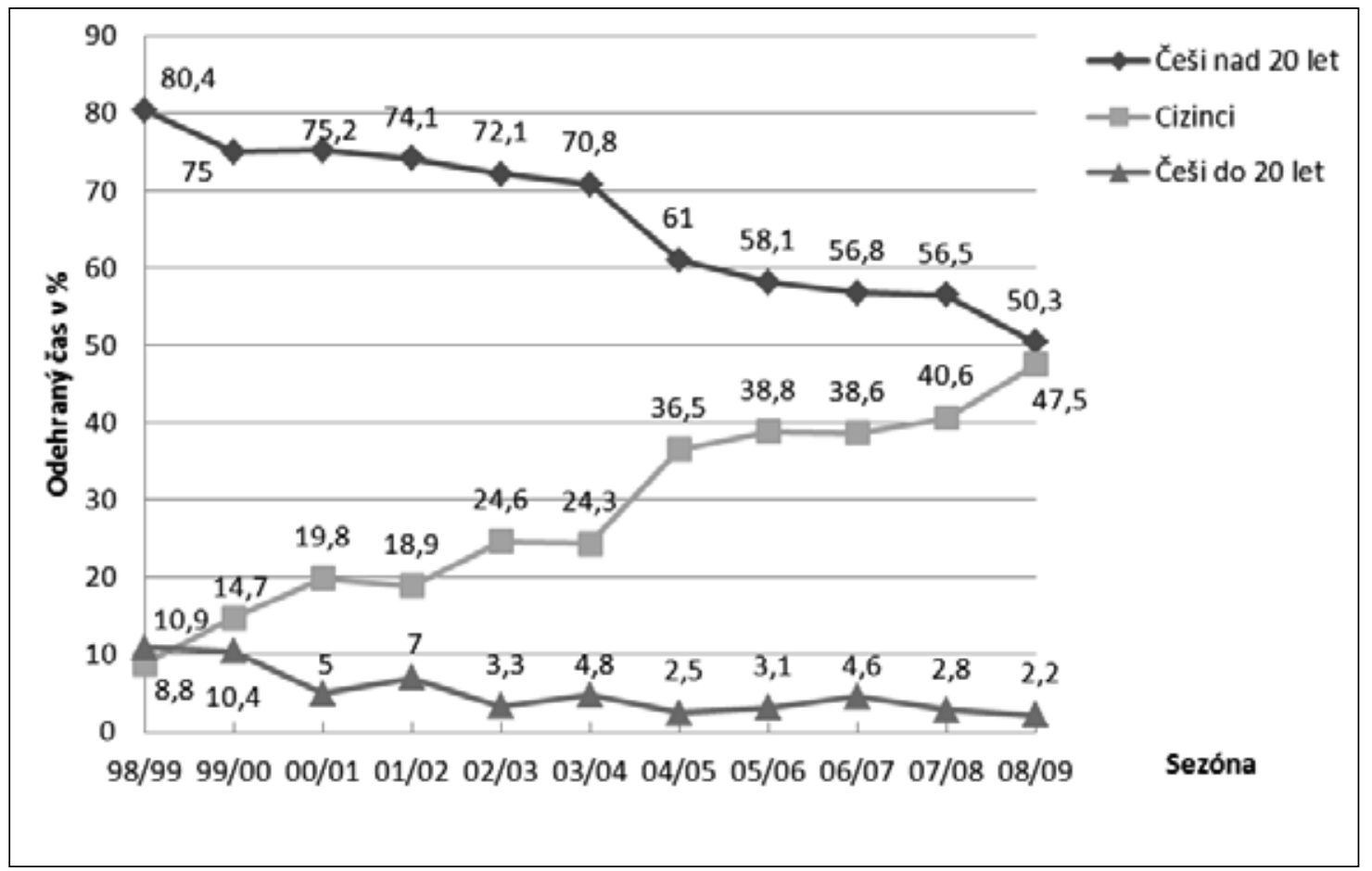

Obrázek 2. Herní čas jednotlivých hráčských skupin

Během sledovaného období došlo k progresivnímu nárůstu odehraných minut v kategorii cizinců (téměř o $40 \%$ ). Na počátku cizinci odehráli zhruba jednu desetinu utkání, v poslední sezóně téměř celou polovinu. Dále je patrné, že dochází ke stálému poklesu odehraných minut u hráčủ do 20 let. V sezóně 1998/99 se jejich odehrané minuty pohybují okolo $10 \%$ hranice. V posledních sezónách se tato hranice snížila až na $2,2 \%$ v roce 2008/09. Markantní pokles odehraných minut u Čechů nad 20 let je spjatý s výrazným nárůstem cizinců (viz Obrázek 2) a malým využíváním mladých českých hráčů. Po 11 letech odehrála česká hráčská garnitura starší než 20 let o 30,1\% herního času méně. Trend je téměř identický s hráčským složením.

$\mathrm{V}$ hráčské charakteristice - počet vstřelených bodů, dochází rovněž k bouřlivým dynamickým změnám ve prospěch zahraničních hráčů. Z $10 \%$ podílu v sezóně 1998/99 vzrostl u nich tento ukazatel na více než polovinu všech dosažených bodů $(53 \%)$ v extralize mužů. Hráči mladší 20 let už po ročníku 2000/01 se propadli z 10,1\% na 4\%. Po stagnaci kolem této hranice se jejich bodový podíl dostal pod $2 \%$. Druhá, česká skupina hráčů (nad 20 let), se z původního téměř $81 \%$ podílu na dosažených bodech dostala v hodnoceném období na 45\%. Blíže viz Obrázek 3.

Pokud se týká komplexního hodnocení prospěšnosti hráče pro družstvo, vyjádřeného koeficientem užitečnosti zjistili jsme podobné tendence jako u předchozích charakteristik. Tento stav je dán logikou věci, protože dílčí charakteristiky participují v koeficientu užitečnosti hráče. V sezóně 1998/99 se užitečnost zahraničních hráčů pohybovala zhruba okolo jedné desetiny $(11,8 \%)$. V průběhu sledované epizody stoupl tento údaj na $54,2 \%$ v roce $2008 / 09$. Je zajímavé, že mezi počtem zahraničních hráčủ a koeficientem užitečnosti není přímá úměra. Koeficient užitečnosti stoupal u cizinců každý rok, bez ohledu na to 
jaký byl jejich počet $\mathrm{v}$ daném roce. U hráčů české národnosti mladších než 20 let se koeficient užitečnosti výrazně snížil po sezóně 99/00, kdy se propadl z hodnoty 10,2\% na 4\%. Pokles pokračoval i v dalších letech až na hodnotu $1,2 \%$ v roce 2004/05 a 2007/08. Pokles koeficientu užitečnosti v poslední kategorii, hráčů starších než 20 let je rovněž velmi výrazný, činí 34,8\%.

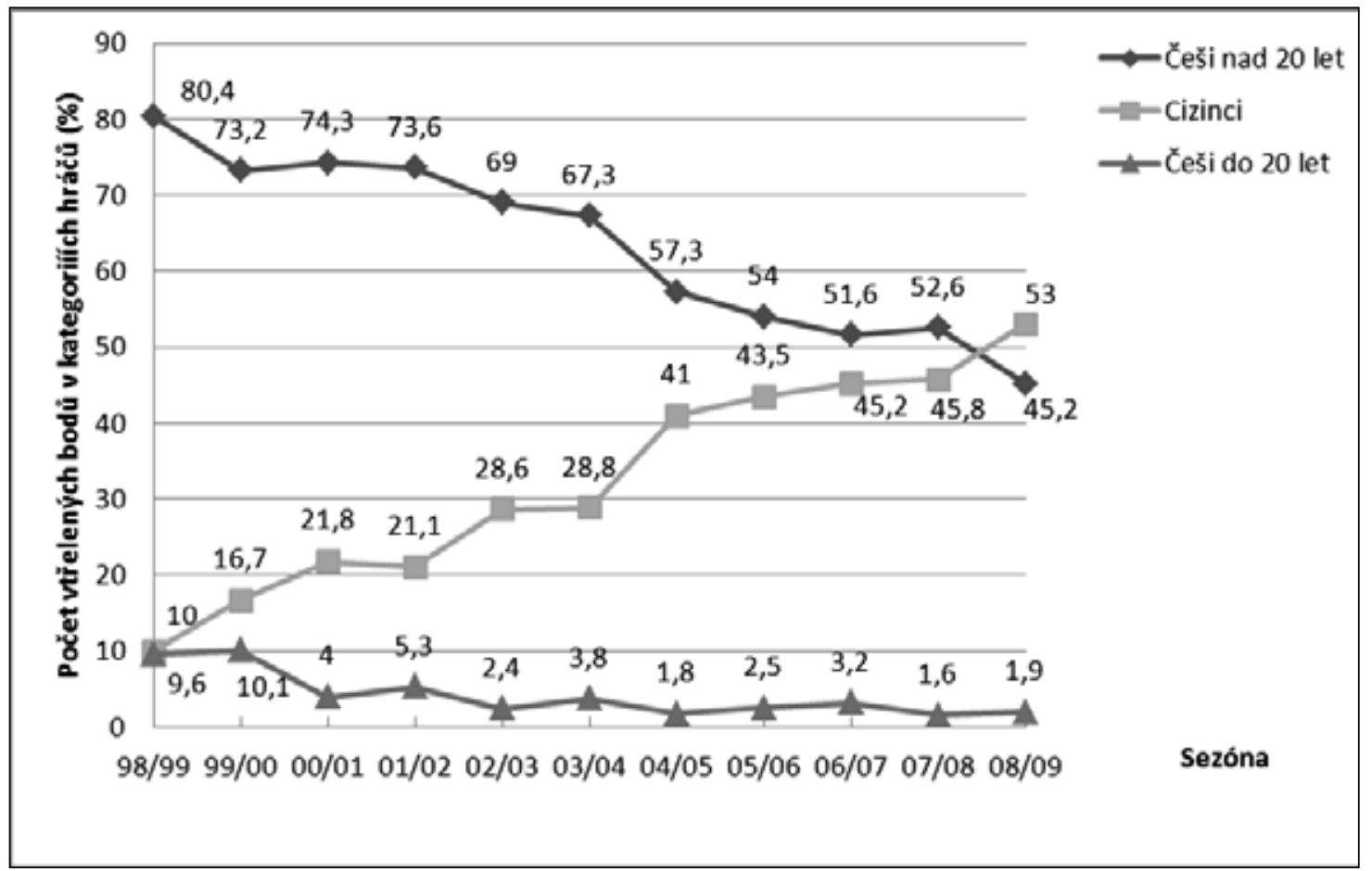

Obrázek 3. Počet dosažených bodů.

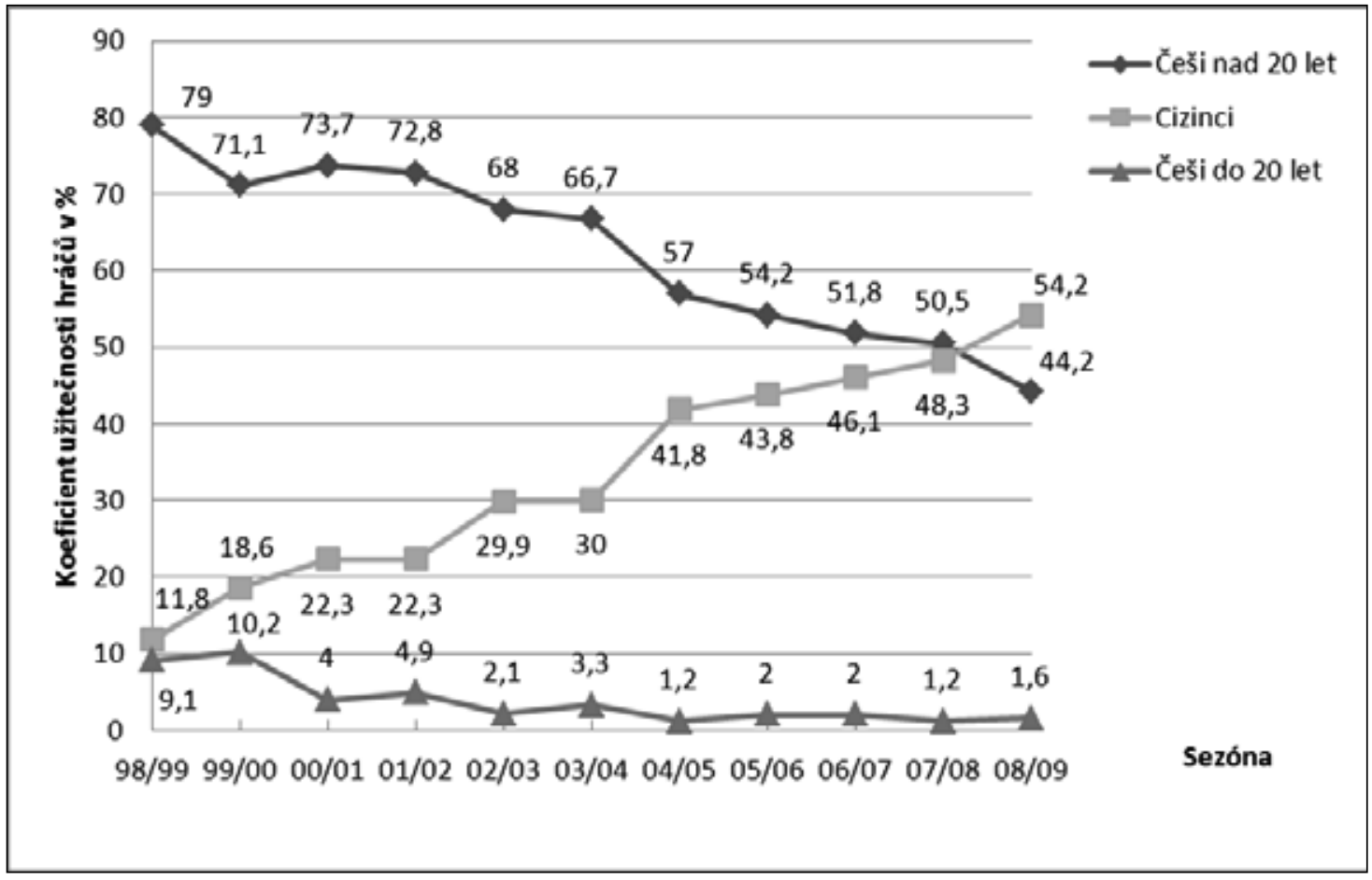

Obrázek 4. Koeficient užitečnosti hráčů. 


\section{ZÁVĚRY}

Basketbalová extraliga mužů od sezóny1998/99 do posledního sledovaného ročníku 2008/2009 se výrazně obměnila ve všech čtyřech sledovaných charakteristikách - počet hráčů, odehrané minuty, vstřelené body a koeficient užitečnosti. Hlavní roli zde sehrává zvýšený zájem o angažování cizinců do českých klubů. Jejich zastoupení v NBL vzrostlo od roku 1998/99 ze 7,6\% na 41,8\% v roce 2008/09. Vlivem tohoto nárůstu pochopitelně dochází k menšímu zapojení českých hráčů mladších než 20 let a vysokému propadu Čechů nad 20 let. Pokud sestavíme nejlepší desítku, dvacítku a třicítku nejlepších hráčů NBL převahu vždy zaujímají cizinci. Stanovené hypotézy byly potvrzeny.

Vzhledem k neustálému poklesu mužské členské základny, zhoršení schopnosti konkurence na reprezentačním poli a nedostatku prostoru pro růst mladých talentů v extraligových utkáních se nad touto aktuální tématikou začíná diskutovat. Je to krok správným směrem, protože již v několika týmech dochází k situacím, že na palubovce není ani jeden český hráč. Dále čeští hráči nemívají tak dominantní útočné pokyny jako cizinci, na které padá větší tíha odpovědnosti za výsledky družstva. Vedení ČBF se proto po letech zvyšování klubových kvót pro cizince odhodlalo pro jejich postupné snížení. Tento krok probíhá až od aktuální sezóny 2009/10, která již není začleněna do našeho sledování. Současný basketbalový trend českým basketbalistům př́liš nekonvenuje. Basketbal v celosvětovém měřítku preferuje atletické pojetí hry a to se promítá i v české nejvyšší basketbalové soutěži (cf. Stone, Perry, \& Darley, 1997). Podotýkáme, že v naší studii, jsme se somatotypem hráčů nezabývali.

\section{Literatura}

DOBRÝ, L. \& VELENSKÝ, E. Košíková. Teorie a didaktika. Praha: SPN, 1987 (2. vydání). DOBRÝ, L. \& SEMIGINOVSKÝ, B. Sportovní hry. Výkon a trénink. Praha: Olympia, 1988. DOVALIL, J., BUNC, V., HOŠEK, V., CHOUTKA, V., PERIČ, T., POTMĚŠIL, J., SVOBODA, B., \& VRÁNOVÁ, J. Výkon a trénink ve sportu. Praha: Olympia, 2009. (3. vydání). ISBN 80-7376-130-1.

CINGIENE, V. \& LASKIENE, S. A revitalized dream: basketball and national identity in Lithuana. The International Journal of the History of Sport, 2004, 21(5), 762-779. ISSN 1743-9035.

GALILY, Y., \& SHEARD, K. Cultural Imperialism and Sport: The americanization of Israeli basketball. Sport in Society: Culture, Commerce, Media, Politics, 2002, 5(2), 55-78. ISSN 1743-0445.

NYKODÝM, J., CHVÁTALOVÁ, M., MISSBACH, Z., PĚTIVLAS, T., PROCHÁZKA, R., STAREC, P., STRACHOVÁ, M., VILÍM, M., \& VEČEǨA. K. Teorie a didaktika sportovních her. Brno: MU, 2006. ISBN 80-210-4042-4.

OSTOJIC, S. M., MAZIC, S., \& DIKIC, N. Profiling in basketball: Physical and psychological characteristics of elite players. Journal of Strenght and Conditioning Research, 2006, 20(4), 740-744. ISSN 1533-4287. PERIČ, T. Výběr sportovních talentů. Praha: Grada, 2006. ISBN 80-247-1827-8.

ROSE, H. L. The basketball handbook. Campaign, IL: Human Kinetics, 2004. ISBN 073-604-9061.

SAMPAIO, J., JANIERA, M., IBANEZ, S., \& LORENZO, A. Discriminant analysis of game related statistics between basketball guards, forwards and centres in three profesional leagues. European Journal of Sport Science, 2006, 6(3), 173-178. ISSN 1536-7290.

SHOR, E. \& YONAY, Y. Sport, national identity, and media discourse over foreign athletes in Israel. Nationalism and Ethnic Politics, 2010, 16(3), 483-503. ISSN 1557-2986.

SMITH, R. Velká encyklopedie basketbalu. Praha: Václav Svojtka \& Co., 1998. ISBN 80-723-713-71.

STONE, J., PERRY, W., \& DARLEY, P. M. „White Men Can’t Jump“: Evidence for the Perceptual Confirmation of Racial Stereotypes Following a Basketball Game. Basic and Applied Social Psychology, 1997, 19(3), 291-306. ISSN 1532-4834.

VELENSKÝ, M. Basketbal: herní trénink, kondiční trénink, technika, taktika. Praha: Grada, 1999. ISBN 80-7969-834-2.

www.cbf.cz/souteze/vysvetlivky.html

www.cbf.cz 
www.cbf.cz/souteze.html

www.msmt.cz/sport/agendy

www.cbf.cz/sbt/

www.fiba.com/pages/eng/fc/FIBA/quicFact/p/openNodeIDs/962/selNodeID/962/quicFacts.html 